\title{
SEASONAL WORK IN HUNGARY IN THE LIGHT OF SEASONAL WORK DIRECTIVE SEZÓNNA PRÁCA V MAĎARSKU VO SVETLE SMERNICE PRE SEZÓNNU PRÁCU
}

\author{
Vera ÁCS*
}

\section{Introduction}

Hungary has little available information on third country workers in seasonal employment. What is known is that the seasonal workers coming to Hungary typically belong to the 35-44 year-old age group, with the 25-34 and 45-54 yearolds also significantly represented ${ }^{(1)}$ and they form unskilled or low-skilled labour force. In 2008 Hungary had basically nationals from Romania, Serbia and Ukraine who made up the bulk of holders of seasonal work permits. However, nowadays seasonal work permits are granted solely to Ukrainian nationals due to free movement of workers provisions and

(1) See EMN focused study 2012, Intra-EU mobility of third-country nationals, Hungary, p. 18. http://ec.europa.eu/dgs/homeaffairs/what-we-do/networks/european_migration_network/ reports/docs/emn-studies/intra-eu-mobility/12a._hungary_national_report_intra-eu_mobility_en_final_feb2013_en.pdf

\section{Abstract (EN)}

The Seasonal Work Directive forms part of the EU's sectoral immigration policy, as there is a permanent need for unskilled labour within the EU. The Directive introduces the common admission standards with simplified entry procedures and the prospect of returning in a subsequent season in the sectors which are identified seasonal - most notably agriculture, horticulture and tourism - where work undertaken mostly by third country nationals. As safeguards against economic and social exploitation the Directive also establishes a common set of rights to which third country seasonal workers are entitled during their stay, which, at the same time, also protects EU citizens who are seasonal workers from unfair competition. Today, Hungary is not a target country for seasonal employment. The Directive not only gives an obligation to the Member States but also gives a good chance to make their country more attractive for temporary migration.

\section{Keywords (EN)}

Hungary, EU, seasonal workers, third country nationals, equal treatment visa exemption. Since 2009 Romanian workers do not need a work permit in Hungary and as of 2010 the Serbian citizens are exempted from visa obligation.

Seasonal work on the Hungarian labour market is getting more and more unattractive for third country nationals form year to year, while in 2006 more than 2000 seasonal work permits were issued, this number drastically fell down under 1000 in 2007 and as of 2009 the number has never arisen above $500^{(2)}$. However, there has been a continuous decrease

(2) Seasonal agricultural work permits numbered 696 in 2008, this number shrank to 368 in 2009, in 2010 an increase to 470 followed due to more seasonal workers from Ukraine who accounted for 460 of the 470 . In 2011 only Ukrainian citizens (380 of them) were granted seasonal work permits. By 2012 the number decreased to a mere 168. In 2013 there was a high increase $(64,9 \%)$ in seasonal employment, altogether 280 seasonal work permits were issued ( 273 for Ukrainians and 7 for Serbians.) Data source: National Labour Office, See Report on the main features of the foreigners working in Hungary in 2013. [A külföldi munkavállalók magyarországi munkavállalásának

\section{Abstrakt (SK)}

Smernica týkajúca sa sezónnej práce tvorí súčast' sektorovej imigračnej politiky EÚ, nakol'ko po nekvalifikovanej pracovnej sile v rámci EÚ jestvuje permanentý dopyt. Smernica zavádza spoločné normy so zjednodušenými postupmi pre vstup a lepšie vyhliadky na návrat v nasledujúcej sezóne v odvetviach, ktoré sú označené ako sezónne - v najväčšej miere je to polnohospodárstvo, záhradníctvo a cestovný ruch - kde sa vo velkej miere uplatňujú štátni príslušníci tretích krajín. Ako ochranu proti hospodárskemu a sociálnemu vykoristovaniu, smernica zavádza práva, na ktoré majú nárok sezónni pracovníci z tretích krajín počas ich pobytu, a ktoré pred nekalou sútažou chránia tiež občanov EÚ pracujúcih sezónne. V súčasnosti Madarsko nie je cielovou krajinou pre sezónne práce. Smernica nestanovuje len povinnosti pre členské krajiny, ale poskytuje tiež šancu na zatraktívnenie týchto krajín pre dočasnú migráciu.

\section{Klúčové slová (SK)}

Madarsko, EÚ, sezónni pracovníci, obyvatelia tretích krajín, rovnaké zaobchádzanie

\footnotetext{
Szeged University, Hungary
} 
also in the numbers of general work permit since 2004 which showed a gradual decline after accession due to the transition period applied by Hungary. ${ }^{(3)}$ Nevertheless, Hungary has never been a main destination country for immigrants but rather a typical transit country along the migration routes towards the western countries of the European Union. In respect to the migrants whose target country was primarily Hungary the major countries of origin were Romania, Ukraine, Germany, China and Serbia. The migrants mainly came from the neighbouring countries and most of them were ethnic Hungarians. This situation has been changed in the last few years; the most general work permits were issued to Chinese, Vietnamese workers and nationals from Kosovo. From the neighbouring countries the numbers of work permit issued for Serbians in 2013 were almost the same as in 2012. On the other hand, there was a $60,5 \%$ decline in the numbers of Ukrainian workers in 2013, which is a really sharp cut down comparing the data to data from 2012. The migrants from Serbia and Ukraine have moderated in the last few years, which means only one thing that the neighbouring countries whose workers had represented a major part of both the general and the seasonal work permits in Hungary do not chose Hungary for the purpose of employment any more either in the form of general employment or seasonal employment. ${ }^{(4)}$

On 26 February 2014, the European Parliament and the Council of the European Union adopted the Directive on the conditions of entry and stay of third country nationals ${ }^{(5)}$ for the purpose of seasonal work (hereinafter: Directive) $)^{(6)}$. The Directive does not only respond to a political mandate $e^{(7)}$ but forms part of the EU's efforts to develop a comprehensive immigration policy. According to the explanatory memorandum of the proposal there is a more permanent need for unskilled labour within the EU. ${ }^{(8)}$ In the impact assessment ${ }^{(9)}$ the Commission emphasized that the unskilled labour are not

főbb sajátosságai 2013-ban]. http://nfsz.munka.hu/engine.aspx? page=stat_kulf_munkavall_mo-on

(3) Although there was an increase in the numbers of work permit from 2012 to 2013 due to the migrants arriving from Asia (China, Vietnam and Japan).

(4) On 31 December 2013 there were only 2 valid seasonal work permits in Hungary out of the valid work permits.

(5) Third-country national means any person who is not a citizen of the Union within the meaning of Art 20(1) TFEU.

(6) OJ L 94/375 28.3.2014

(7) As a consequence of the Hague Programme of November 2004, the Commission presented a policy plan on legal migration (COM (2005) 669) which provided for the adoption of five legislative proposals on labour immigration, including a proposal for a Directive on the conditions of entry and residence of seasonal workers The European Pact on Immigration and Asylum, adopted by the European Council on 15 and 16 October 2008, expresses the commitment of the European Union and its MSs to conduct a fair, effective and consistent policy for dealing with the challenges and opportunities of migration. The Commission and Council's commitment established in the Policy Plan on Legal Migration adopted in 2005 was also reiterated by the Stockholm Programme adopted by the Council on 10-11 December 2009.

(8) $\operatorname{COM}(2010) 379$. p.2

(9) SEC (2010) 887 attractive for EU citizens, they are usually fulfilled by third country nationals and there is significant evidence that certain third-country seasonal workers face exploitation and sub-standard working conditions which may threaten their health and safety. Moreover, third country nationals are often irregular migrants staying illegally in the Member States (hereinafter: MSs.) Therefore, the Directive sets out common rules for entry and stay for seasonal workers who are not EU citizens. By introducing the common admission standards with simplified entry procedures and the prospect of returning in a subsequent season the Directive hopefully will provide for flexible admission to endow the EU labour market with the necessary resources in the sectors which are identified seasonal - most notably agriculture, horticulture and tourism - where work undertaken mostly by third country nationals. As a safeguard against economic and social exploitation the Directive also establishes a common set of rights to which third country seasonal workers are entitled during their stay which, at the same time, also protects EU citizens who are seasonal workers from unfair competition.

In this article I will introduce the current Hungarian legislation from the point of seasonal employment and the rights of a seasonal worker which will be touched upon and modified very shortly due to the implementation of the Directive (by 30 September 2016 at the latest.) I am going to highlight the substantive provisions of the current system which shall be changed. By analysing the Directive and the Hungarian legislation, I try to make a conclusion whether in a couple of year's time it will be more attractive than nowadays for a third country national to work as a seasonal worker in Hungary due to the new EU Directive.

\section{Directive}

In spite of the harmonized admission criteria, MSs are free to determine the volume of admissions and impose a labour market test (Art. 8.3.) If a MS decides to admit seasonal workers, it is obliged to adopt a procedure in line with the Directive. It means that the Directive prevents MSs from admitting seasonal workers through other migration systems. The only exception is bilateral and multilateral agreements, if they have more favourable provisions for the seasonal workers. ${ }^{(10)}$

The Directive only applies to third country nationals ${ }^{(1)}$ who reside outside the territory of the MSs(12) and who apply to be admitted, or who have been admitted under the terms of the

(10) They are either concluded between the Union or between the Union and its MSs on the one hand and one or more third countries on the other or between one or more MSs and one or more third countries.

(11) It shall not apply to third-country nationals who are carrying out activities on behalf of undertakings established in another MS in the framework of the provision of services, including third-country nationals posted by undertakings established in a MS in the framework of the provision of services in accordance with Directive 96/71/EC. It shall not apply to those third country nationals either who are family members of Union citizens who have exercised their free movement rights.

(12) The Directive shall not apply to third-country nationals who at the time of application reside in the territory of a MS. (Art. 2.1.) 
Directive, to the territory of a MS for the purpose of employment as seasonal workers. (Art.2.1) Seasonal worker means a third-country national who retains his/her principal place of residence in a third country and stays legally and temporarily in the territory of a MS to carry out an activity dependent on the passing of the seasons, under one or more fixed-term work contracts concluded directly between that third-country national and the employer established in that MS (Art. 3.b) Although the Directive covers direct working relationships between seasonal workers and employers, where a MS's national law allows admission of third-country nationals as seasonal workers through employment or temporary work agencies established on its territory and which have a direct contract with the seasonal worker, such agencies are not excluded. Stemming from, those employers, who are located either in third countries or in other MSs, are excluded from the scope of the Directive.

Seasonal employment, used as 'activity dependent on the passing of the seasons' means an activity that is tied to a certain time of the year by a recurring event or pattern of events linked to seasonal conditions during which required labour levels are significantly above those necessary for usually on-going operations (Art. 3.c) Activities dependent on the passing of the seasons are typically to be found in sectors such as agriculture and horticulture, in particular during the planting or harvesting period, or tourism, in particular during the holiday period. ${ }^{(13)}$

Although the objective was to introduce common admission criteria for seasonal workers, the admission rules had to take into account the Schengen acquis and the Visa code. As a result, the Directive contains six different routes to seasonal employment in a $\mathrm{MS}^{(14)}$. For those workers who are admitted for stays longer than 90 days, the Directive defines both the conditions for admission to and stay in the MS and the criteria and requirements for access to employment in the MSs (Rec.19-22.) MSs can choose between the authorizations for the purpose of seasonal work but they can choose only one system. ${ }^{(15)}$

${ }^{(13)}$ MSs are obliged, where appropriate in consultation with social partners, to list those sectors of employment which include activities that are dependent on the passing of the seasons.

${ }^{(14)}$ In the case of MSs applying the Schengen acquis in full, Regulation (EC) No 810/2009 of the European Parliament and of the Council (Visa Code), Regulation (EC) No 562/2006 of the European Parliament and of the Council (Schengen Borders Code), and Council Regulation (EC) No 539/2001 apply in their entirety. Accordingly, for stays not exceeding 90 days, the conditions for admission of seasonal workers to the territory of the Member States applying the Schengen acquis in full are regulated by those instruments, while this Directive should only regulate the criteria and requirements for access to employment. In the case of Member States not applying the Schengen acquis in full, with the exception of the United Kingdom and Ireland, only the Schengen Borders Code applies. The provisions of the Schengen acquis referred to in this Directive belong to that part of the Schengen acquis in which Ireland and the United Kingdom do not take part and therefore those provisions do not apply to them.

${ }^{(15)}$ For stays not exceeding 90 days, MSs shall issue (a) a shortstay visa, indicating that it is issued for the purpose of seasonal work, (b) or a short-stay visa and a work permit indicating that they are issued for the purpose of seasonal work; (c) or a work permit indicating that it is issued for the purpose of seasonal
It is up to the MSs to decide whether the employee or the employer shall submit the application (Art.12.3). An application for a seasonal worker permit shall be submitted in a single application procedure which means a procedure leading, on the basis of one application for the authorisation of a third-country national's stay and work in the territory of a MS, to a decision on the application for a seasonal worker permit (Art. 3.g)

The application shall be accompanied by a valid work contract or a binding job offer to work as a seasonal worker in the MS concerned with an employer established in that MS which specifies: the place and type of the work, the duration of employment, the remuneration, the working hours per week or month, the amount of any paid leave, other relevant working conditions and if possible, the date of commencement of employment. The Directive also requires that the applicant demonstrate that the migrant is covered by health insurance (Art. 6.1.b) and has adequate accommodation (Art. 6.1.c) and has sufficient resources without having recourse to social assistance (Art.6.3). It is within the discretion of the MSs to determine whether the workers are free to arrange their own accommodation or whether it is the employer's responsibility. ${ }^{(16)}$ In cases where the work contract or binding job offer specifies that the third-country national will exercise a regulated profession ${ }^{(17)}$, the MS may require the applicant to present documentation attesting that the third-country national fulfils the conditions laid down under national law for the exercise of that regulated profession. (Art. 6.6) MSs may require the payment of fees for the handling of applications, which shall not be disproportionate or excessive. Where the third-country national pays those fees, MSs may provide that they are entitled to be reimbursed. Moreover, MSs may require employers to pay for the cost of travel from the seasonal workers' place of origin to the place of work in the MS and the return journey and the cost of sickness insurance. ${ }^{(18)}$

To prevent overstaying of third-country seasonal workers, the MSs shall fix the length of stay for seasonal workers, which shall be not less than 5 months and not more than 9 months in any 12-month period. After the expiry of that period, the third-country national shall leave the MS unless the MS has issued a residence permit for purposes other than seasonal work. MSs may determine a maximum period of time within any 12 -month period, during which an employer is allowed

work, where the third-country national is exempted from the visa requirement. MSs shall provide for either the authorizations referred to in points (a) and (c) or the authorizations referred to in points (b) and (c). For stays exceeding 90 days, MSs shall issue third-country nationals one of the following authorizations for the purpose of seasonal work: a long-stay visa, indicating that it is issued for the purpose of seasonal work, a seasonal worker permit; or a seasonal worker permit and a long-stay visa, if the long-stay visa is required under national law for entering the territory.

(16) If the employer provides accommodation, the Directive contains a number of safeguards. See para 2 of Art 23

(17) See Directive 2005/36/EC of the European Parliament and of the Council on the recognition of professional qualifications, OJ L 255. 30.9.2005. p 22.

${ }^{(18)}$ These costs shall not be recoverable from the seasonal workers. 
to hire seasonal workers. That period shall be not less than the maximum period of stay. (Art. 14.) Within the maximum duration of stay, an extension of the contract or change of employer is possible, provided that the admission criteria continue to be met. The possibility for the seasonal worker to be employed by different employers shall not entail the possibility for the seasonal worker to seek employment on the territory of the MSs, while being unemployed. When MSs decide on the extension of stay or the renewal of the authorisation for the purpose of seasonal work, they are free to apply labour market test. MSs are required to facilitate the re-entry of migrant workers who have been admitted to that MS as seasonal workers at least once within the previous five years. The facilitation depends upon the MSs who are advised to apply one or more measures listed in para 2 Art.16.

In order to prevent exploitation and protect the safety and health of third-country seasonal workers, the Directive expressly embodies the equal treatment principle stating that seasonal workers are entitled to equal treatment with nationals of the host MS at least with regard to nine enumerated of rights (Art. 23.) These include the terms of employment, including the minimum working age, and working conditions, including pay and dismissal, working hours, leave and holidays, as well as health and safety requirements at the workplace; the right to strike and take industrial action and freedom of association and affiliation and membership of an organisation representing workers or of any organisation whose members are engaged in a specific occupation, including the rights and benefits conferred by such organisations, including the right to negotiate and conclude collective agreements, without prejudice to the national provisions on public policy and public security; back payments to be made by the employers, concerning any outstanding remuneration to the third-country national; access to goods and services and the supply of goods and services made available to the public, except housing; advice services on seasonal work afforded by employment offices; education and vocational training; recognition of diplomas, certificates and other professional qualifications in accordance with the relevant national procedures; tax benefits, in so far as the seasonal worker is deemed to be resident for tax purposes in the MS concerned. Moreover, third-country national seasonal workers shall be granted equal treatment in respect of those branches of social security listed in Article 3 of Regulation (EC) No 883/2004 of the European Parliament and of the Council ${ }^{(19)}$ which include sickness benefits, maternity and equivalent paternity benefits, invalidity benefits, old-age benefits, survivors' benefits, benefits in respect of accidents at work and occupational diseases, death grants, unemployment benefits, pre-retirement benefits and family benefits ${ }^{(20)}$. Due to the temporary nature of the stay of seasonal workers and without prejudice to Regulation (EU) No 1231/2010 of the European Parliament and of the Council ${ }^{(21)}$, MSs are able to exclude family benefits and unemployment benefits from equal treatment between seasonal workers and their own nationals and shall be able to limit the application of equal treatment in relation to

\footnotetext{
(19) OJ L 166, 30.4.2004. p.1-123

(20) This Regulation does not cover social assistance.

(21) OJ L 344, 29.12.2010 p. 1.
}

education and vocational training, as well as tax benefits.

\section{Seasonal Work in Hungary}

Each year Hungary determines the volume of third country nationals who are allowed to work in Hungary. This quota, however, does not split into sub-quotas; it involves all third country workers who need either the general work permit or the seasonal work permit (N.B. single permit, e.g. EU Blue Card is also taken into account.) The quota has never been utilized so far, the application has never been rejected either on the ground that the quota is fulfilled. Beside the quota, there is the possibility for the government to decide on in which area of the country or in which professions work permit is not issued to third country nationals at all due to the labour market situation. So far, there has been no such area or profession defined.

In point of the Directive there is no obstacle for Hungary to keep the freedom to determine the volume of admissions and one of the grounds for rejection an application linked to the admission volume.

Worker can be any natural person who carries out work under a work contract ${ }^{(22)}$. Worker is defined in the Labour Code irrespective of the nationality. The Labour Code uses the general term of worker making no differentiation. Worker shall meet the criteria listed in the Labour Code to be a worker ${ }^{(23)}$. Consequently, under the Labour Code any third country national can be a seasonal worker in Hungary. They need, in general, a work permit, or a single permit, in case of agriculture a seasonal work permit. Work contract can be concluded only in the possession of (seasonal) work permit and only for that period of time what is the (seasonal) work permit is valid for. ${ }^{(24)}$ Thus authorisation for work and stay shall be the first action for employing foreigners; the work contract itself follows them. Binding job offer exists only for single procedure ${ }^{(25)}$ and single permit, however, seasonal work does not fall under it (not yet).

The Simplified Employment Act (hereinafter: SEA)(26) involves seasonal work in agriculture and tourism and casual work. ${ }^{(27)}$

\footnotetext{
(22) Act I of 2012 on Labour Code, see Art 34

(23) para 1-2 Art 34 Labour Code

(24) para 3 Art 192 Labor Code
}

(25) The single procedure is based on the application submitted by third country national, which is aimed at the authorization to stay in the territory of Hungary exceeding 90 days and the establishment of a legal employment relationship with a specific employer. Cases e.g. third-country national intends to establish a legal employment relationship, and he/she submits a residence permit application for family reunification, or submits an application for EU Blue Card; or third country national submitting an application for residence permit for gainful activity, etc.

(26) In 2010 the government introduced the Act LXXV of 2010 on Simplified Employment Act to simplify the complicated, slow and dysfunctional administrative burdens for seasonal work and to facilitate both the seasonal and casual employment.

(27) Casual work means fixed-term employment between an employer and employee: for not more than five consecutive working days in total; for not more than fifteen calendar days in total 
SEA is applicable to both EEA nationals - including also the Hungarians - and third country nationals. However, there are some limitations to third country nationals with regard to their legal status in Hungary, and, additionally, with regard to the work which could be carried out by. As a simplified employment third country nationals may take up only agricultural seasonal work, which results that they are totally excluded from the seasonal work in tourism and casual employment. Only those third country nationals who have been living long enough in Hungary, they are holders of permanent residence or immigration permits [so-called 'bevándorló' and 'letelepedett'] can carry out work in all forms of simplified employment without any limitations. These categories of migrants will not fall under the scope of the Directive, firstly, because they do not need any work permit to take up a job in the Hungarian labour market, secondly, they permanently live in Hungary. On the other hand, MSs are free to list up their sectors in seasonal employment, therefore, they can easily exclude some for third country nationals. The exclusion of seasonal work in tourism therefore will be accepted to my opinion.

Seasonal work is defined in a couple of pieces of legislation in Hungary. Firstly, the Labour Code gives a general definition, secondly, it is classified as a simplified employment in the SEA, thirdly, Government decree ${ }^{(28)}$ clarifies for what type of work seasonal work permit is required, and, last but not least, also the act ${ }^{(29)}$ on entry and stay in Hungary deals with it.

Paragraph c Art 90 of the Labour Code defines seasonal work, as it follows: any activity of the employer is treated seasonal if it is linked to a certain period of time or date of the year irrespective of the work organization. Moreover, the Labour Code sets forth special rules applicable to this type of work due to its nature. Under SEA simplified employment involves seasonal work in agriculture and tourism and casual work. For the purposes of SEA seasonal work is defined as a work, which meets the criteria written in the cited para of the Labour Code.

within one calendar month; for not more than ninety calendar days in total within one calendar year. Moreover, there is an additional restriction to casual work: the maximum number of casual workers an employer may employ on the same calendar day shall not exceed: one person, if the employer does not have other full-time employees; two persons, if the employer has one to five full-time employees; four persons, if the employer has six to twenty full-time employees; $20 \%$ of the number of full-time employees, if the employer has more than twenty full-time employees.

(28) Government Decree No 445/2013. (XI.28.) on the employment of third country nationals not on the basis of single procedure and permit [A harmadik országbeli állampolgárok magyarországi foglalkoztatásának nem összevont kérelmezési eljárás alapján történő engedélyezéséről, az engedélyezési kötelezettség alóli mentességról, a fővárosi és megyei kormányhivatal munkaügyi központjának az összevont kérelmezési eljárásban való szakhatósági közremúködéséről, valamint a Magyarországon engedélymentesen foglalkoztatható harmadik országbeli állampolgárok magyarországi foglalkoztatásának bejelentéséról, és a munkabér megtérítéséről szóló 445/2013. (XI. 28.) Korm. rendelet]

${ }^{(29)}$ Act II of 2007 on entry and stay of third county nationals [A harmadik országbeli állampolgárok beutazásáról és tartózkodásáról szóló 2007. évi II. törvény]
Furthermore, it is added that in case of seasonal work in agriculture - although there is a definition for seasonal work in agriculture in SEA - any work that could be carried out only in a certain period or time due to the biological feature of the generated plant or animal shall also be treated as such. For the purposes of SEA, seasonal agricultural work means any work performed in the plant cultivation, forestry, livestock or fishery and hunting sectors which, due to the nature of the goods produced or the service provided, is associated to one of the seasons or any period or time during the year, or the movement of the agricultural products produced within the employer's property, or the packaging thereof, provided that the duration of the fixedterm employment contract between the same parties is not more than 120 days in a calendar year. Seasonal work in tourism is a seasonal work performed for an employer providing commercial services in tourism, provided that the duration of the fixedterm employment contract between the same parties is not more than 120 days in a calendar year.

Government decree defines a special agricultural seasonal work permit, which is available for those third country nationals who want to work in the plant cultivation, forestry, livestock and fishery sectors. N.B. hunting is missing from this definition, which can result in such an interpretation that in case of hunting agricultural seasonal work permit is not required. Instead of, general work permit might be required. It also stemming from the abovementioned definition, those other types of work, which are beyond plant cultivation, forestry, livestock and fishery, they are not under seasonal work permit obligation. They might be even out of seasonal work. However, under SEA only the plant cultivation, forestry, livestock and fishery sectors are open to third country nationals (with seasonal work permit, while hunting is open without it), seasonal work in tourism is totally exempted. The construction sector, which is generally treated as a place of seasonal work in many MSs, is not defined as a seasonal work either from the point of special work permit or simplified employment. Work on a construction site can be a casual work, which is also totally closed for third country nationals.

The definition of seasonal work does not seem to be problematic from the point of the Directive, it might be in line with the it. However, it will be good to make the different definitions consistent with each other in the national law.

In case of seasonal work, there is neither a single procedure, nor a single permit system. Single permit system is not a new phenomenon in Hungary due to the implementation of the Directive 2011/98/EU on single permit ${ }^{(30)}$. This procedure shall be broadening also for the application for seasonal work permit and seasonal visa, which will definitely facilitate the procedure for the applicants and will be more client friendly.

Application for seasonal work permit shall be submitted by the employer who is also obliged to make a labour demand notification to the government office situated in the area where the

\footnotetext{
30) Directive 2011/98/EU of the European Parliament and of the Council of 13 December 2011 on a single application procedure for a single permit for third-country nationals to reside and work in the territory of a MS and on a common set of rights for thirdcountry workers legally residing in a MS
} 
prospective work will take place ${ }^{(31)}$. Labour demand notification shall be valid in order to get a seasonal work permit. Labour demand notification is valid, if it is submitted together with the application form for seasonal work permit; or it was submitted earlier but not later than 60 days or it was submitted earlier than 60 days but it was renewed within 60 days before the application form was submitted. Labour demand notification shall contain the same information as the application form for seasonal work permit (e.g. wage, job description, place of work etc.). In the labour demand notification the employer shall describe the job what he/she expects from the worker to do. The government office checks in its registration whether there is a Hungarian/EEA national workforce available (labour market test). There is no labour market test, if the seasonal work does not take 60 days. Between 61-180 days within a calendar day labour market test is needed. In one permit more periods of seasonal work can be defined. If the seasonal work is less than 60 days, the application form cannot be denied on the reason of the employer's invalid labour demand notification. In case of seasonal work the government office does not checks whether the seasonal worker meets all the criteria required to get the job (e.g professional qualification). Third country nationals are generally not allowed to work in Hungary through temporary work agencies. Seasonal workers are exceptions; they can work also via temporary work agencies.

There is no problem to keep the labour market test either when the application is submitted or when it is renewed. I do not think that labour demand notification made by the employer will not be in line with the admission criteria, as the MSs can apply labour market tests. Labour demand notification serves information on vacancies, on the basis of, the government office is able to follow the labour market situation. There is no obstacle to use temporary work agencies in the future to take seasonal workers, however, the temporary agencies shall be established in Hungary. I wonder whether Hungary can keep that provision in force in the future "... the government office does not check whether the seasonal worker meets all the criteria required to get the job (e.g. professional qualification)." I cannot see any obstacle why it should be changed.

There is no limit for the length of seasonal work in the Labour Code. Limitations are stemming from the visa rule, rules on the work permit procedure and simplified employment. Under SEA, if an employer and an employee establish an employment relationship more than once for seasonal work, or for seasonal and casual work (the latter is out of question from the point of third country newcomers), the aggregate duration of such employment relationships may not be longer than 120 days over the calendar year. Although the seasonal work permit would allow a longer stay (up to 180 days within a calendar year) and employment in seasonal work

\footnotetext{
(31) Apart from this there is a general obligation for the employers to notify all vacancies to the government office where the employment will take place under a work contract. See Decree of Minister for Economy No 30/2000 (IX.15.) on labour market services and labour market supports [a munkaerőpiaci szolgáltatásokról, valamint az azokhoz kapcsolódóan nyújtható támogatásokról szóló 30/2000. (IX. 15.) GM rendelet]
}

for third country nationals, the SEA limits it by 120 days. Seasonal work permit cannot be prolonged or renewed.

Seasonal work can be carried out only in possession of a seasonal work permit and a seasonal work visa. A seasonal work visa shall be obtained if the seasonal employment exceeds three months. The seasonal work visa entitles to a single entry or to multiple entries and for staying for more than 3 months but for the maximum of 6 months for the purpose of undertaking seasonal work. The seasonal work visa is valid for one year at the most.

Hungary shall change the length of stay for the purpose of seasonal work in line with the Directive, which shall be more favourable for the seasonal worker. There is no minimum stay required, only the procedural rules are different according to time periods e.g. less than 60 days (no labour market test) or more than 3 months of stay (seasonal visa required). There is an obligation to fix a minimum stay, which is for the seasonal worker. It shall be definitely longer than the no minimum criterion. The maximum period of time can stay just like as it is now because it falls under the maximum time defined in the Directive. However, it will be desirable to make a longer stay for seasonal workers. As a new element it shall be introduced into the system that seasonal work permit can be prolonged or renewed. Besides, in the future the seasonal worker shall have the possibility to change his/her employer within his/her stay, which is out of question nowadays.

As we saw above, there is no single way to admit a seasonal worker in a MS; therefore Hungary can easily keep its system in this way as it is now.

The third country seasonal worker, in person, shall submit the application for seasonal work visa unless he/she is unable to appear due to his/her state of health. The prospective seasonal worker is required to have the seasonal work permit issued by the competent government office in Hungary to the employer, which shall be attached to the application form. The permit shall contain the place and dates of work; and in the case of multiple employments, the data concerning each employment.

As I indicated above, the system shall be reconsidered point by point how the procedure for seasonal work permit and seasonal visa can fit into the current single procedure system. I do not think that it will result an enormous change in the procedure, to my opinion it will easily absorb the seasonal work permit and seasonal visa.

A seasonal work visa may be issued to a third country national who holds a valid travel document; has a permit required for return or onward travel; certifies the purpose of his/her entry and stay; has place of accommodation or domicile in Hungary; has the financial means that cover the costs of dwelling and subsistence for the entire period of stay, as well as the costs of the outward travel; qualifies as insured person with respect to health services, or is able to cover the costs of the health services provided to him/her; is not subject to expulsion, prohibition of entry and stay, and his/her entry and stay does not pose a risk to the public security, national security, and public health interests of Hungary; who is not subject to an SIS warning signal ordering prohibition of entry and stay. There are some documents, which shall be 
attached to the application form ${ }^{(32)}$, which proves the abovementioned criteria. The seasonal work as the purpose of stay can be proven with either a work permit or a document certifying a legal relationship for employment (N.B. work contract can be undersigned when the work permit and visa are issued.)

Criteria and requirements for admission as a seasonal worker for stays either not exceeding or exceeding 90 days are already in line with the Directive. However, there are some may clauses in the Art concerned which let the MSs to introduce new criteria. It shall be decided whether Hungary requires the accommodation of the seasonal worker arranged by or through the employer and if the decision is appropriate, what documentation shall be required to submit. Nevertheless, it should bear in mind that although there is a room for MSs to define the criteria and requirements for admission, the list of requirements and criteria are closed in spite of may clauses. It will be relevant when the MSs draw up a list why an application shall or may be rejected. Although the Directive consists of many types of ground of rejection or withdrawal of an application (see shall; shall, if appropriate; may), the MSs are not allowed to be creative and introduce new ones; they shall remain in the given framework.

Hungary has no provisions on facilitation re-entry of third-country nationals. It will be obliged to introduce one of the measures which are recommended to the MSs in para 2 Art 16.

There is an administrative service fee for issuing the visa, which equals to $40 \mathrm{EUR}$, however, for the seasonal work permit there is no service fee.

There is no problem to keep or change the fee as long as it is not disproportionate or excessive. Third country nationals pay for visa; therefore, Hungary may provide that third country seasonal workers are entitled to be reimbursed.

The diplomatic or consular mission shall make the decision on the application for a seasonal work visa within 15 days. No appeal can be submitted against the decision made on the application for a seasonal work visa or the revoking of the visa.

If the single procedure will be introduced for seasonal employment, the decision taking process will be longer. However, the current single procedure system is already in line with the Directive because decision is taken not later than 90 days from the date on which the complete application was submitted. Hungary shall provide that the decision shall be open to legal challenge either it is declaring inadmissible an application for authorisation for the purpose of seasonal work or rejecting the application, refusing an extension of stay or renewal of an authorisation for the purpose of seasonal work or withdrawing an authorisation for the purpose of seasonal work.

To protect the worker, an employment relationship for the purposes of simplified employment may not be established between parties for whom an employment relationship already exists. ${ }^{(33)}$ If the employment relationship is not

\footnotetext{
(32) Available on the website of Office of Immigration and Nationality (www.bmbah.hu)

(33) See para 2 Art 201 of Labour Code.
}

established for the purposes of simplified employment, the employment contract may not be modified with a view to allowing the employer to employ the employee within the framework of simplified employment. Nevertheless, if someone is in simplified employment, he/she is allowed to establish an employment relationship with his/her employer according to the Labour Code. Employment status shall be stated in a mutually agreed simplified work contract, which is enclosed to SEA.

I do not think there is any obstacle written in the Directive to conclude other fix term work contract between the seasonal worker and the same employer, which concerns other employment than seasonal work.

The employment relationship in simplified work is established by notifying the tax authorities. ${ }^{(34)}$ The employer is required to make such a notification prior to the commencement of work by a simple text message (SMS) or electronically via the so-called client gate system ${ }^{(35)}$ after being registered once in the system. ${ }^{(36)}$

Simplified employment is very popular among the Hungarians, because, with respect to the obligation of paying personal income tax and contributions, the amount of public dues payable by the employer are, irrespective of the wage and the daily working hours. In case of seasonal work in agriculture or tourism, per calendar day of employment per employee HUF 500 shall be paid. In case of casual work, per calendar day of employment per employee HUF 1,000 shall be paid. The employee does not pay any public dues. One hundred percent of the paid net wage must be considered as income from simplified employment. The worker does not have to file a declaration about the income from simplified employment, unless - he/she is a foreign citizen, or his/her income from simplified employment in the relevant tax year exceeds HUF 840,000 , or - in addition to the income from simplified employment, he/she did not have any income subject to a tax return, apart from earnings qualifying as emoluments not subject to taxation.

A controversial paragraph concerns entitlements to social benefits. During simplified employment the employees do not have overall and regular social security; they are not insured persons. They are only entitled to accident health care services (emergency healthcare services) and job seeking allowances. Additionally, they have only a restricted pension claims for the period of this kind of employment.

Union law does not limit the power of the MSs to organise their social security scheme. It is for the MS to lay down the conditions under which social security benefits are granted, as well as the amount of such benefits and the period for which they are granted. However, when exercising that pow-

\footnotetext{
(34) Art para 2 Art 2 of Labour Code.

(35) See https://ugyfelkapu.magyarorszag.hu/

(36) The notification submitted to the tax authority may be withdrawn or modified in the event that the nature of employment is changed or the work does not take place - within two hours after notification was sent, or - if, according to the notification, employment started on the day following the date of notification, or if the notification included an employment relationship longer than one day, modifications are allowed by 8:00 hours on the day of notification.
} 
er, MSs should comply with Union law. Therefore, Hungary shall think about whether there is any social security benefit, which should be given to seasonal workers under the Directive. If the Hungarian seasonal workers are not insured during seasonal work, due to the Directive Hungary shall not have to provide social insurance for third country nationals either because equal treatment applies with nationals of host MSs. If the conditions are rather poor in seasonal employment for Hungarian nationals, the same will apply to also third country nationals.

Hungary shall take a decision whether it shall restrict equal treatment by excluding family benefits and unemployment benefits, by limiting its application to education and vocational training which is directly linked to the specific employment activity and by excluding study and maintenance grants and loans or other grants and loans, with respect to tax benefits by limiting its application to cases where the registered or usual place of residence of the family members of the seasonal worker for whom he/she claims benefits, lies in the territory of Hungary.

\section{Conclusion}

Over the past fifteen years, the EU has followed a sectoral approach to legal migration. This track has resulted in legal frameworks for highly skilled workers ${ }^{(37)}$, low-skilled workers, namely seasonal workers and intra corporate transferees $^{(38)}$.

These Directives embody immigration law which regulates entry and stay of certain categories of persons in the territory of a MS and recognize their rights linked to the stay and work. A Framework Directive for all other categories of migrant workers providing a single permit has also been adopted $^{(39)}$. Many Directives have been watered down during the negotiations due to the different interests of the stakeholders, therefore, many experts state "...these Directives fall well short of the Commission's goal of a common immigration policy for the EU." ${ }^{(40)}$ However, they accept that this Seasonal Work Directive differs significantly from the other immigration Directives. This Directive provides an exclusive route for admission excluding MSs's temporary migration schemes with a robust equal treatment provisions while giving enough room for MSs to flexibly enforce it.

(37) Council Directive 2009/50/EC of 25 May 2009 on the conditions of entry and residence of third-country nationals for the purposes of highly qualified employment, OJ L 155/17, 18.6.2009

(38) Directive 2014/66/EU of the European Parliament and of the Council of 15 May 2014 on the conditions of entry and residence of third-country nationals in the framework of an intra-corporate transfer, OJ L 157/1 27.5.2014

(39) Directive 2011/98/EU of the European Parliament and of the Council of 13 December 2011 on a single application procedure for a single permit for third-country nationals to reside and work in the territory of a Member State and on a common set of rights for third-country workers legally residing in a Member State, OJ L 343/1 23.12.2011

(40) See FUDGE, J. - HERZFELD OLSSON, P.:The EU seasonal workers Directive: When Immigration Controls Meet Labour Rights, European Journal of Migration and Law, 16 (2014) 465.
In Hungary, apart from the economical circumstances and the state of play of the labour market, the success of the Directive is based upon how Hungary will give effect to this Directive in its national law, how much Hungary is willing to protect third country national seasonal workers.

The Directive itself guaranties many more favourable provisions for seasonal workers, which shall be transposed into national law than provisions applicable in Hungary today. More client friendly procedure, procedural safeguards, facilitation of re-entry, renewability of stay and work, sanctions against employers are some examples from those few elements of the Directive which may invite third country nationals as seasonal workers to Hungary. However, these advantages and rights will be available in all MSs.

How charming and attractive a MS will be for a third country national for the purpose of seasonal work will significantly depend on the 'may clauses' of the Directive. How a 'may clause' will be used by a MS whether it will mean a limitation for third country national (e.g. excluding certain rights from equal treatment) or not applying a may clause which will result in becoming a more attractive MS which provides family benefits and/or unemployment benefits or study and maintenance grants and loans or other grants and loans etc. to third country nationals, or a 'may clause' will give a real chance for picking up a living (e.g. longer period of stay for seasonal work) or provides more safety (e.g. accommodation, fees born by the employer etc.)

As we saw, this Directive has the potential to make Hungary and of course the EU more attractive for third country nationals and to give more protection for seasonal workers. It depends on Hungary how it will utilise it.

\section{References}

1. FUDGE, J. - HERZFELD OLSSON, P., 2014. The EU seasonal workers Directive: When Immigration Controls Meet Labour Rights, European Journal of Migration and Law, 16 (2014) 465.

2. National Labour Office. 2013. Report on the main features of the foreigners working in Hungary in 2013. [A külföldi munkavállalók magyarországi munkavállalásának főbb sajátosságai 2013-ban], [available online] <http://nfsz.munka.hu/ engine.aspx?page=stat_kulf_munkavall_mo-on>.

3. Act II of 2007 on entry and stay of third county nationals [A harmadik országbeli állampolgárok beutazásáról és tartózkodásáról szóló 2007. évi II. törvény].

4. Act I of 2012 on the Labor Code adopted by Parliament on 13 December 2011.

5. Council Regulation (EC) No 539/2001.

6. Council Regulation (EC) No 562/2006 of the European Parliament and of the Council (Schengen Borders Code).

7. Council Regulation (EC) No 810/2009 of the European Parliament and of the Council (Visa Code).

8. Decree of Minister for Economy No 30/2000 (IX.15.) on labour market services and labour market supports [a munkaerőpiaci szolgáltatásokról, valamint az azokhoz kapcsolódóan nyújtható támogatásokról szóló 30/2000. (IX. 15.) GM rendelet].

9. Directive 2005/36/EC of the European Parliament and of the Council on the recognition of professional qualifications.

10. Directive 2009/50/EC of 25 May 2009 on the conditions of entry and residence of third-country nationals for the purposes of highly qualified employment, OJ L 155/17, 18.6.2009.

11. Directive 2011/98/EU of the European Parliament and of the 
Council of 13 December 2011 on a single application procedure for a single permit for third-country nationals to reside and work in the territory of a Member State and on a common set of rights for third-country workers legally residing in a Member State, OJ L 343/1 23.12.2011.

12. Directive 2014/36/EU of the European Parliament and of the Council of 26 February 2014 on the conditions of entry and stay of third-country nationals for the purposes of employment as seasonal workers.

13. Directive 2014/66/EU of the European Parliament and of the Council of 15 May 2014 on the conditions of entry and residence of third-country nationals in the framework of an intracorporate transfer, OJ L 157/1 27.5.2014.

14. Government Decree No 445/2013. (XI.28.) on the employment of third country nationals not on the basis of single procedure and permit [A harmadik országbeli állampolgárok magyarorszá- gi foglalkoztatásának nem összevont kérelmezési eljárás alapján történő engedélyezéséről, az engedélyezési kötelezettség alóli mentességről, a fővárosi és megyei kormányhivatal munkaügyi központjának az összevont kérelmezési eljárásban való szakhatósági közremúködéséről, valamint a Magyarországon engedélymentesen foglalkoztatható harmadik országbeli állampolgárok magyarországi foglalkoztatásának bejelentéséről, és a munkabér megtérítéséről szóló 445/2013. (XI. 28.) Korm. rendelet].

\section{Contact address/ Kontaktná adresa}

Vera ÁCS

PhD. student at Szeged University, Faculty of Law, Department of Social and Labour Law, Szeged, Dugonics tér 13, 6720 Hungary 